\title{
Differences in biological efficiency of one- and two-component graminicide on sugar beet crops in Tula region
}

\author{
Kristina D. Kryukova $\bowtie$, Valeriya O. Gresis \\ Peoples’ Friendship University of Russia (RUDN University), Moscow, Russian Federation \\ $\varangle$ Corresponding author: k_kryukova@inbox.ru
}

\begin{abstract}
One of the most urgent tasks in sugar beet production for Russia today is irregularities in cultivation technology and a low-efficiency crop protection. It leads to a high level of weed infestation of agricultural fields. Developing and identifying the most efficient, selective and accessible herbicides, which have low phytotoxicity, do not have a negative effect on soil chemical characteristics and can be used in sugar beet cultivation is relevant today. The aim of this study was to examine and compare biological efficiency of various doses and concentrations of one- and two-component graminicides on sugar beet crops against the following weeds: Cockspur grass - Echinochloa crusgalli (L.) Beauv., Wild millet — Setaria glauca (L.) Beauv. and Couch Grass - Elytrigia repens (L.) Nevski. The experiment was conducted on the territory of the Tula region in 2020. The total field experiment area was $480 \mathrm{~m} 2$. Application of clethodim + quizalofop-P-ethyl $(0.5 \mathrm{l} / \mathrm{ha}$ ) resulted in reducing the number and weight of annual weeds by $64 \ldots . .71 \%$, reducing the number and weight of perennial weeds by $54 . .58 \%$, which had the same efficiency as clethodim ( $0.6 \mathrm{l} / \mathrm{ha})$. The efficiency of clethodim + quizalofop-P-ethyl (1.0 l/ha) was higher than Clethodim ( $0.6 \mathrm{l} / \mathrm{ha})$ and amounted to $73 . . .87 \%$ of reduction in the number of weeds compared to the control, but was lower than Clethodim (1.8 l/ha), which resulted in $89 . . .95 \%$ reduction in the number of weeds compared to the control. The highest sugar beet yields were obtained in the variants with clethodim (1.8 l/ha) and two-component herbicide (1 l/ha), which amounted to 28 and $25 \%$ yield increase, in comparison with the control.
\end{abstract}

Keywords: sugar beet, biological efficacy, pesticide, herbicide, graminicide, clethodim, quizalofop-P-ethyl

Conflict of interest. The authors declare that they have no conflict of interests.

\section{Article history:}

Received: 5 May 2021. Accepted: 1 June 2021

For citation:

Kryukova KD, Gresis VO. Differences in biological efficiency of one- and two-component graminicide on sugar beet crops in Tula region. RUDN Journal of Agronomy and Animal Industries. 2021; 16(2):129—136. doi: 10.22363/2312-797X-2021-16-2-129-136

(C) Kryukova K.D., Gresis V.O., 2021

This work is licensed under a Creative Commons Attribution 4.0

International License https://creativecommons.org/licenses/by/4.0/1 


\section{Introduction}

Sugar beet is one of the most important industrial crops in Russia and has a great national and economic importance. The main advantage of sugar beet is high yields and productivity, which can reach $50 \mathrm{t} / \mathrm{ha}$, depending on the region, the cultivation technology and cultivar characteristics [1, 2].

Sugar beet is a highly weed-sensitive crop. There are over 75 species of weeds that cause significant damage to sugar beet production. In turn, human economic activity leads to changes in the stable species composition of weeds in a field community [3-5].

Nowadays, highly profitable sugar beet production is impossible without the integrated crop protection system against weeds. Integrated protection includes a complex of agrotechnical, biological, chemical and other methods of weed control. First of all, the main task is to regulate the number of harmful objects on sugar beet crops to the threshold of economic harmfulness [6].

In Russia, there is a high weed infestation of fields, which is associated with a violation of crop rotation rules, soil cultivation systems, a decrease in the use of chemical herbicides, and, the number of such fields is growing [3-5]. According to various sources, there are no production fields in the country without weeds. About $75 \%$ of the area requires constant weed control and a lot of appropriate measures [5].

Number of weed seeds in the arable soil layer increased 1.5 fold in beet-growing regions [1]. The number and species composition of weeds is also increasing, including perennial and harmful weeds [7-11].

In this study, a field experiment was carried out on sugar beets using graminicides based on clethodim and a mixture of clethodim with quizalofop-P-ethyl [12]. These active substances have proven effectiveness in many countries, have a high biological efficiency and do not harm sugar beet plants [13-19].

Thus, developing and identifying the most efficient, selective and accessible herbicides, which have low phytotoxicity, do not have a negative effect on soil chemical properties and can be used in sugar beet cultivation is relevant today [1, 5, 6].

The aim of this study was to examine and to compare biological efficiency of various doses and concentrations of one- and two-component graminicides against annual and perennial cereal weeds on sugar beet crops in the Tula region (active substances: clethodim; clethodim + quizalofop-P-ethyl).

\section{Materials and methods}

The objects were plots and weeds in the sugar beet field in the Tula region. The research subjects were the following harmful objects:

1. Couch Grass - Elytrigia repens (L.) Nevski.

2. Cockspur grass - Echinochloa crusgalli (L.) Beauv.

3. Wild millet - Setaria glauca (L.) Beauv.

The cultivated plants were sugar beets (Beta vulgaris L.) of one-seeded mid-ripening sugary hybrid — 'Okean'.

Seeding rate: 1.1 sowing unit. Plant growth stage treated: $4-6$ true leaves. Forecrop: winter wheat. Tillage: in autumn - plowing to a depth of $25 \mathrm{~cm}$, in spring presowing harrowing and cultivation. 
The experiment has variants:

1. Control (without any chemical graminicide treatment).

2. Graminicide with active ingredient of clethodim (120 g/l). Application rate: 0.6 l/ha.

3. Graminicide based on clethodim (120 g/l). Application rate: 1.8 l/ha.

4. Graminicide based on clethodim and quizalofop-P-ethyl (140 g/l + $70 \mathrm{~g} / \mathrm{l}$, respectively). Application rate: $0.5 \mathrm{l} / \mathrm{ha}$.

5. Graminicide based on clethodim and quizalofop-P-ethyl (140 g/l + $70 \mathrm{~g} / \mathrm{l}$, respectively). Application rate: $1.0 \mathrm{l} / \mathrm{ha}$.

Consumption of working solution: 200 l/ha. Frequency of treatments: 1 . Spraying was carried out in the phase of $2 \ldots 4$ leaves in weeds and regardless of the growth stage of sugar beet plants. The period of herbicide action: during the growing season.

The total field experiment area was $480 \mathrm{~m}^{2}$. The size of each experimental plot was $60 \mathrm{~m}^{2}$, and the record plot was $24 \mathrm{~m}^{2}$. The protective stripes were 3 meters wide and were not counted.

Quantitative-weighting method was used on accounting sites with a size of $1.0 \mathrm{~m}^{2}$ on each plot of the experiment. Counting the yield was carried out by a mechanical method from the entire area of the plots, statistical data processing - the technique of analysis of variance (ANOVA). The counts of harmful objects (weeds) were carried out before treatment, 30 and 45 days after treatment, and before harvesting.

\section{Results and discussion}

The influence of one- and two-component graminicide with different consumption rates on the total weed infestation of sugar beet crops and on certain types of weeds is shown in Table 1 and 2.

Effect of graminicides on weeds (Tula region, 2020)

\begin{tabular}{|c|c|c|c|c|}
\hline \multirow{2}{*}{ Variant } & \multirow{2}{*}{ Date } & \multicolumn{3}{|c|}{ Decrease of weeds, \% to control } \\
\hline & & Cockspur grass & Wild millet & Couch grass \\
\hline \multirow{3}{*}{ 1. Clethodim, $120 \mathrm{~g} / \mathrm{l}$, rate $-0.6 \mathrm{I} / \mathrm{ha}$} & 17.07 & 50 & 67 & 56 \\
\hline & 01.08 & 68 & 66 & 58 \\
\hline & 23.09 & 72 & 78 & 67 \\
\hline \multirow{3}{*}{ 2. Clethodim, $120 \mathrm{~g} / \mathrm{l}$, rate $-1.8 \mathrm{I} / \mathrm{ha}$} & 17.07 & 94 & 97 & 93 \\
\hline & 01.08 & 99 & 98 & 97 \\
\hline & 23.09 & 100 & 100 & 98 \\
\hline \multirow{3}{*}{$\begin{array}{l}\text { 3. Clethodim, } 140 \mathrm{~g} / \mathrm{l}+\text { quizalofop-P-ethyl } 70 \mathrm{~g} / \mathrm{l} \text {, } \\
\text { rate }-0.5 \mathrm{l} / \mathrm{ha}\end{array}$} & 17.07 & 75 & 73 & 61 \\
\hline & 01.08 & 73 & 73 & 58 \\
\hline & 23.09 & 82 & 76 & 62 \\
\hline \multirow{3}{*}{$\begin{array}{l}\text { 4. Clethodim, } 140 \mathrm{~g} / \mathrm{l}+\text { quizalofop-P-ethyl } 70 \mathrm{~g} / \mathrm{l} \text {, } \\
\text { rate }-1.0 \mathrm{l} / \mathrm{ha}\end{array}$} & 17.07 & 96 & 85 & 80 \\
\hline & 01.08 & 97 & 90 & 81 \\
\hline & 23.09 & 97 & 93 & 91 \\
\hline \multirow{3}{*}{ 5. Control* } & 17.07 & 21 & 41 & 23 \\
\hline & 01.08 & 23 & 42 & 25 \\
\hline & 23.09 & 20 & 42 & 22 \\
\hline
\end{tabular}

*The control contains data on the number of weeds, plants $/ \mathrm{m}^{2}$ 
Influence of active ingredients and their rates and concentrations on total weed infestation of sugar beet crops (Tula region, 2020)

\begin{tabular}{|c|c|c|c|c|c|c|c|c|c|}
\hline \multirow{3}{*}{ Variant } & \multirow{3}{*}{ Date } & \multicolumn{4}{|c|}{ Number of weeds } & \multicolumn{4}{|c|}{ Weed mass } \\
\hline & & \multicolumn{2}{|c|}{ Plants $/ \mathrm{m}^{2}$} & \multicolumn{2}{|c|}{$\begin{array}{c}\text { Decrease, \% } \\
\text { to control }\end{array}$} & \multicolumn{2}{|c|}{$\mathrm{G} / \mathrm{m}^{2}$} & \multicolumn{2}{|c|}{$\begin{array}{c}\text { Decrease, } \% \\
\text { to control }\end{array}$} \\
\hline & & Annual & Perennial & Annual & Perennial & Annual & Perennial & Annual & Perennial \\
\hline \multirow{3}{*}{$\begin{array}{c}\text { 1. Clethodim, } \\
120 \mathrm{~g} / \mathrm{l} \text {, rate - } \\
0.6 \mathrm{l} / \mathrm{ha}\end{array}$} & 17.07 & 22 & 10 & 62 & 56 & 63 & 48 & 68 & 59 \\
\hline & 01.08 & 18 & 9 & 67 & 58 & 59 & 43 & 72 & 64 \\
\hline & 23.09 & 16 & 8 & 74 & 67 & - & - & - & - \\
\hline \multirow{3}{*}{$\begin{array}{c}\text { 2. Clethodim, } \\
120 \mathrm{~g} / \mathrm{l} \text {, rate - } \\
1.8 \mathrm{l} / \mathrm{ha}\end{array}$} & 17.07 & 13 & 4 & 96 & 93 & 23 & 9 & 88 & 92 \\
\hline & 01.08 & 10 & 2 & 98 & 97 & 18 & 6 & 92 & 95 \\
\hline & 23.09 & 7 & 1 & 100 & 98 & - & - & - & - \\
\hline \multirow{3}{*}{$\begin{array}{l}\text { 3. Clethodim, } \\
140 \mathrm{~g} / \mathrm{l}+ \\
\text { quizalofop- } \\
\text { P-ethyl } 70 \mathrm{~g} / \mathrm{l} \text {, } \\
\text { rate - } \\
0.5 \mathrm{l} / \mathrm{ha}\end{array}$} & 17.07 & 21 & 11 & 74 & 61 & 71 & 54 & 64 & 53 \\
\hline & 01.08 & 19 & 10 & 73 & 58 & 63 & 51 & 70 & 58 \\
\hline & 23.09 & 15 & 9 & 79 & 62 & - & - & - & - \\
\hline \multirow{3}{*}{$\begin{array}{l}\text { 4. Clethodim, } \\
140 \mathrm{~g} / \mathrm{l}+ \\
\text { quizalofop- } \\
\text { P-ethyl } 70 \mathrm{~g} / \mathrm{l} \text {, } \\
\text { rate - } \\
1.0 \mathrm{l} / \mathrm{ha}\end{array}$} & 17.07 & 15 & 11 & 92 & 80 & 37 & 43 & 81 & 63 \\
\hline & 01.08 & 11 & 8 & 93 & 81 & 28 & 35 & 87 & 71 \\
\hline & 23.09 & 7 & 5 & 94 & 91 & - & - & - & - \\
\hline \multirow{3}{*}{ 5. Control } & 17.07 & 62 & 23 & - & - & 195 & 116 & - & - \\
\hline & 01.08 & 65 & 25 & - & - & 212 & 120 & - & - \\
\hline & 23.09 & 62 & 22 & - & - & - & - & - & - \\
\hline
\end{tabular}

In variants without any chemical graminicide treatments and using only mechanical treatment of crops, the number of studied annual cereal weeds has reached about 65 or more plants per $1 \mathrm{~m}^{2}$, and the number of perennial cereal weeds has reached about 25 plants and more per $1 \mathrm{~m}^{2}$.

The initial infestation of sugar beet crops with Setaria weeds averaged 41 plants per $1 \mathrm{~m}^{2}$, Cockspur grass averaged 21 plants per $1 \mathrm{~m}^{2}$, and for Couch Grass the average infestation was 23 weeds per $1 \mathrm{~m}^{2}$.

Based on the data obtained, the least effective variants were graminicide based on clethodim, $120 \mathrm{~g} / \mathrm{l}$, consumption rate - $0.6 \mathrm{l} / \mathrm{ha}$ and graminicide based on clethodim $140 \mathrm{gl}$ and quizalofop-P-ethyl $70 \mathrm{~g} / \mathrm{l}$, consumption rate - $0.5 \mathrm{l} / \mathrm{ha}$. Clethodim at a concentration of $120 \mathrm{~g} / \mathrm{l}$, consumption rate $0.6 \mathrm{l} /$ ha destroyed about $64 \%$ of perennial grasses and about $74 \%$ of annual grasses. Similar results were noted in variant with clethodim $140 \mathrm{~g} / \mathrm{l}$ and quizalofop-P-ethyl $70 \mathrm{~g} / \mathrm{l}$, with a consumption rate of $0.5 \mathrm{l} / \mathrm{ha}$, which destroyed about 59 \% of perennial cereal weeds and about $76 \%$ of annual cereal weeds.

The medium efficacy in this study was shown by a herbicide based on clethodim at a concentration of $140 \mathrm{~g} / \mathrm{l}$ and quizalofop-P-ethyl at a concentration of $70 \mathrm{~g} / \mathrm{l}$ with a 
consumption rate of $1.0 \mathrm{l} / \mathrm{ha}$, reducing the number of studied annual and perennial weeds by 94 and $91 \%$, respectively. This agent with a consumption rate of $1.0 \mathrm{l} / \mathrm{ha}$ is inferior in terms of biological efficiency only to a herbicide based on clethodim, $120 \mathrm{~g} / \mathrm{l}$ with a consumption rate of $1.8 \mathrm{l} / \mathrm{ha}$.

The best biological efficiency in this study was recorded in variant with clethodim at a concentration of $120 \mathrm{~g} / \mathrm{l}$ and consumption rate of $1.8 \mathrm{l} / \mathrm{ha}$. The weed decrease was $95 \%$ and more for annual weeds and $98 \%$ and more for perennial weeds compared to the control, i.e. at a given consumption rate of this agent based on clethodim at a concentration of $120 \mathrm{~g} / \mathrm{l}$, it almost completely destroys all weeds studied in this research and completely destroys annual weeds. The effect of this formulation and consumption rate was superior in biological effectiveness compared to the effect of other investigated graminicides.

The yield of sugar beet root crops of the 'Okean' hybrid, depending on the formulation and the consumption rate used, is shown in Table 3. Date of harvesting: September 23, 2020.

Table 3

Sugar beet productivity depending on the graminicides and their consumption rates (Tula region, 2020)

\begin{tabular}{|l|c|c|}
\hline \multicolumn{1}{|c|}{ Variant } & Average yield, $\mathrm{t} / \mathrm{ha}$ & \% to control \\
\hline 1. Clethodim, $120 \mathrm{~g} / \mathrm{l},-0.6 \mathrm{l} / \mathrm{ha}$ & 26.4 & 118 \\
\hline 2. Clethodim, $120 \mathrm{~g} / \mathrm{l},-1.8 \mathrm{I} / \mathrm{ha}$ & 28.6 & 128 \\
\hline 3. Clethodim, $140 \mathrm{~g} / \mathrm{l}+$ quizalofop-P-ethyl $70 \mathrm{~g} / \mathrm{l},-0.5 \mathrm{l} / \mathrm{ha}$ & 26.5 & 119 \\
\hline 4. Clethodim, $140 \mathrm{~g} / \mathrm{l}+$ quizalofop-P-ethyl $70 \mathrm{~g} / \mathrm{l},-1.0 \mathrm{l} / \mathrm{ha}$ & 27.8 & 125 \\
\hline 5. Control & 22.3 & 100 \\
\hline
\end{tabular}

LSD05 $=1.6 \mathrm{t} / \mathrm{ha}$.

The average yield of sugar beet root crops without the use of the studied graminicides in the control was $22.3 \mathrm{t} / \mathrm{ha}$.

In the variants with the use of the studied graminicides, significant increases in the yield of sugar beet were obtained, which averaged $18 \ldots 28 \%$.

The largest increase in the yield of sugar beet reached $28 \%$ for the formulation based on clethodim at a concentration of $120 \mathrm{~g} / \mathrm{l}$ at a consumption rate of $1.8 \mathrm{l} / \mathrm{ha}$, while the average yield of crops was $28.6 \mathrm{t} / \mathrm{ha}$.

The lowest increase in yield among the studied graminicides was 18 and $19 \%$ for the formulation based on clethodim at a concentration of $120 \mathrm{~g} / \mathrm{l}$ with a consumption rate of $0.6 \mathrm{l} / \mathrm{ha}$ and for the formulation based on clethodim at a concentration of $140 \mathrm{~g} / \mathrm{l}$ with quizalofop-P -ethyl at a concentration of $70 \mathrm{~g} / \mathrm{l}$ with a consumption rate of $0.5 \mathrm{l} / \mathrm{ha}$, respectively, and the average yield of sugar beet was 26.4 and 26.5 t/ha, respectively. 
The medium result in the increase of sugar beet productivity was $25 \%$ in the formulation based on clethodim at a concentration of $140 \mathrm{~g} / \mathrm{l}$ with quizalofop-P-ethyl at a concentration of $70 \mathrm{~g} / \mathrm{l}$ with a consumption rate of $1.0 \mathrm{l} / \mathrm{ha}$. The average yield of sugar beet was $27.8 \mathrm{t} / \mathrm{ha}$.

\section{Conclusions}

The most effective was a herbicide formulation based on clethodim at a concentration of $120 \mathrm{~g} / \mathrm{l}$ with a consumption rate of $1.8 \mathrm{l} / \mathrm{ha}$. Also, an effective result was shown by clethodim $140 \mathrm{~g} / \mathrm{l}$ with quizalofop-P-ethyl $70 \mathrm{~g} / \mathrm{l}$ with a consumption rate of $1.0 \mathrm{l} / \mathrm{ha}$. The lowest biological effectiveness among studied agents was noted in graminicides based on clethodim, $120 \mathrm{~g} / \mathrm{l}$ with a consumption rate of $0.6 \mathrm{l} / \mathrm{ha}$ and Clethodim, $140 \mathrm{~g} / \mathrm{l}$ with Quizalofop-P-ethyl $70 \mathrm{~g} / \mathrm{l}$ with a consumption rate of 0.5 l/ha. The use of pesticides was safe for the protected crop and did not have any negative visual effects.

\section{References}

1. Gureev II. Sovremennye tekhnologii vozdelyvaniya i uborki sakharnoi svekly [Modern technologies of cultivation and harvesting of sugar beets]. Moscow: Pechatnyi gorod publ.; 2011.

2. Shpaar D, Sushkov M. Vyrashchivanie sakharnoi svekly [Cultivation of sugar beet]. Moscow: Agropromizdat publ.; 1996.

3. Artokhin KS. Sornye rasteniya [Weed plants]. Moscow: Pechatniy gorod publ.; 2010.

4. Bazdyrev GI. Zashchita sel'skokhozyaistvennykh kul'tur ot sornykh rastenii [Protection of agricultural crops from weeds]. Moscow; 2004.

5. Spiridonov YY. Integrated crop protection program against weeds. Zashchita i karantin rastenii. 2000;(2):18-20.

6. Nikitin NV, Spiridonov YY, Shestakov VG. Nauchno-prakticheskie aspekty tekhnologii primeneniya sovremennykh gerbitsidov $v$ rastenievodstve [Scientific and practical aspects of the technology of using modern herbicides in crop production]. Moscow: Pechatniy gorod publ.; 2010.

7. Gamuev VV, Gamuev OV. Protection of sugar beet from weeds. Zemledelie. 2013;(4):29—31.

8. Gamuev VV, Smirnov MA. Promising methods of protecting sugar beet from weeds. Zemledelie. 2015;(5):37-39.

9. Dvoryankin EA. The advantages of modern schemes of herbicides used in beet crops. Sakharnaya svekla. 2009;(1):33-36.

10. Ivaschenko AA. Sugar beet weed protection. Zashchita i karantin rastenii. 2005;(10):17-18.

11. Ivaschenko AA. Modern trends in protection of sugar beet from weeds. Zashchita i karantin rastenii. 2005;(2):26-30.

12. Gosudarstvennyi katalog pestitsidov i agrokhimikatov, razreshennykh $k$ primeneniyu na territorii Rossiiskoi Federatsii. Chast'I. Pestitsidy [State catalog of pesticides and agrochemicals permitted for use on the territory of the Russian Federation. Part I. Pesticides]. Moscow: Ministry of Agriculture; 2020.

13. European Food Safety Authority, Anastassiadou M, Brancato A, Carrasco Cabrera L, Ferreira L, Greco L, Jarrah S, Kazocina A, Leuschner R, Magrans JO, Miron I, Pedersen R, Raczyk M, Reich H, Ruocco S, Sacchi A, Santos M, Stanek A, Tarazona J, Theobald A and Verani A. Review of the existing maximum residue levels for clethodim according to Article 12 of Regulation (EC) No 396/2005. EFSA Journal. 2019;17(5):5706. doi: 10.2903/j.efsa.2019.5706

14. Osterholt M, Webster E, Blouin D, McKnight B. Overlay of residual herbicides in rice for improved weed management. Weed Technology. 2019;33(3):426—430. doi: 10.1017/wet.2019.22

15. Mesnage R, Biserni M, Balu S, Frainay C, Poupin N, Jourdan F, et al. Integrated transcriptomics and metabolomics reveal signatures of lipid metabolism dysregulation in HepaRG liver cells exposed to PCB126. Archives of Toxicology. 2018;92(8):2533-2547. doi: 10.1007/s00204-018-2235-7

16. Mesnage R, Biserni M, Wozniak E, Xenakis T, Mein CA, Antoniou MN. Comparison of transcriptome responses to glyphosate, isoxaflutole, quizalofop-p-ethyl and mesotrione in the HepaRG cell line. Toxicology Reports. 2018;5:819—826. doi: 10.1016/j.toxrep.2018.08.005 
17. Biserni M, Mesnage R, Ferro R, Wozniak E, Xenakis T, Mein CA, et al. Quizalofop-p-Ethyl induces adipogenesis in 3T3-L1 adipocytes. Toxicological Sciences. 2019;170(2):452 —461. doi: 10.1093/toxsci/kfz097

18. Jankowska M, Kaczynski P, Lozowicka B. Metabolic profile and behavior of clethodim and spirotetramat in herbs during plant growth and processing under controlled conditions. Scientific Reports. 2020;10(1):1323. doi: 10.1038/s41598-020-58130-3

19. Guldiken B, Ozkan G, Catalkaya G, Ceylan FD, Yalcinkaya IE, Capanoglu E. Phytochemicals of herbs and spices: Health versus toxicological effects. Food and Chemical Toxicology. 2018;119,37—49. doi: 10.1016/j. fct.2018.05.050

\title{
About authors:
}

Kryukova Kristina Dmitrievna - Master student, Agrobiotechnology department, Agrarian and Technology Institute, Peoples' Friendship University of Russia (RUDN University), 8/2, Miklukho-Maklaya st., Moscow, 117198, Russian Federation; e-mail: k_kryukova@inbox.ru

Gresis Valeriya Olegovna - PhD student, Assistant Professor, Agrobiotechnology department, Agrarian and Technology Institute, Peoples’ Friendship University of Russia (RUDN University), 8/2, Miklukho-Maklaya st., Moscow, 117198, Russian Federation; e-mail: gresis_vo@pfur.ru

\section{Изучение различий биологической эффективности применения одно- и двухкомпонентного граминицида на сахарной свекле в условиях Тульской области}

\author{
К.Д. Крюкова $ه$, В.О. Гресис \\ Российский университет дружбы народов, г. Москва, Российская Федерация \\ $\square$ k_kryukova@inbox.ru
}

\begin{abstract}
Аннотация. Одна из наиболее актуальных проблем при возделывании сахарной свеклы в России нарушение технологии выращивания и низкоэффективная защита данной культуры, что приводит к высокой засоренности полей. Разработка и подбор наиболее высокоэффективных, селективных и доступных гербицидов, которые обладают низкой фитотоксичностью и не ухудшают химических свойств почвы, для применения на посевах сахарной свеклы остается актуальной по сей день. Цель данного исследования - изучить биологическую эффективность применения различных доз одно- или двухкомпонентных граминицидов на посевах сахарной свеклы против таких сорных растений, как пырей ползучий (Elytrigia repens (L.) Nevski), куриное просо (Echinochloa crusgalli (L.) Beauv.), щетинник сизый (Setaria glauca (L.) Beauv). Исследование проводилось территории Тульской области в 2020 г. Общая площадь опыта составила $480 \mathrm{~m}^{2}$. Использование нормы расхода действующих веществ клетодим + хизалофоп-П-этил с нормой расхода 0,5 л/га снижало количество и массу однолетних злаковых сорняков на $64 . . .71 \%$, количество и массу многолетних злаковых сорняков на $54 . .58$ \%, что было на уровне эффективности использования нормы расхода действующего вещества клетодим 0,6 л/га. Эффективность нормы расхода 1,0 л/га препаративной формы на основе клетодима + хизалофоп-П-этила была выше эффективности нормы расхода 0,6 л/га препаративной формы на основе клетодима, но ниже эффективности нормы расхода 1,8 л/га препаративной формы на основе клетодима. Наибольшую прибавку урожайности получили при использовании норм расхода 1,8 л/га препаративной формы на основе клетодима -28 \% и 1 л/га двухкомпонентного гербицида - $25 \%$.
\end{abstract}

Ключевые слова: сахарная свекла, биологическая эффективность, пестицид, гербицид, граминицид, клетодим, хизолофоп-П-этил

Заявление о конфликте интересов: Авторы заявляют об отсутствии конфликта интересов.

\section{История статьи:}

Поступила в редакцию: 5 мая 2021 г. Принята к публикации: 1 июня 2021 г. 
Для цитирования: Kryukova K.D., Gresis V.O. Differences in biological efficiency of one- and two-component graminicide on sugar beet crops in Tula region // Вестник Российского университета дружбы народов. Серия: Агрономия и животноводство. 2021. Т. 16. № 2. С. 129-136. doi: 10.22363/2312-797X-2021-16-2-129-136

\section{Библиографический список}

1. Гуреев И.И. Современные технологии возделывания и уборки сахарной свеклы: практическое руководство. 2-е изд., перераб. и доп. М.: Печатный город, 2011. 256 с.

2. Шпаар Д., Сушков М. Выращивание сахарной свеклы. М.: Агропромиздат, 1996. 144 с.

3. Артохин К.С. Сорные растения. М.: Печатный город, 2010. 272 с.

4. Баздырев Г.И. Защита сельскохозяйственных культур от сорных растений. М., 2004. 328 с.

5. Спиридонов Ю.Я. Программа интегрированной защиты посевов от сорной растительности // Защита и карантин растений. 2000. № 2. С. 18-20.

6. Никитин Н.В., Спиридонов Ю.Я., Шестаков В.Г. Научно-практические аспекты технологии применения современных гербицидов в растениеводстве. М.: Печатный город, 2010. 200 с.

7. Гамуев В.В., Гамуев О.В. Защита сахарной свеклы от сорной растительности // Земледелие. 2013. № 4. С. 29-31.

8. Гамуев В.В., Смирнов М.А. Перспективные способы защиты сахарной свеклы от сорной растительности // Земледелие. 2015. № 5. С. 37-39.

9. Дворянкин Е.A. Преимущества современных схем гербицидов, применяемых в свекловичных посевах // Сахарная свекла. 2009. № 1. С. 33-36.

10. Иващенко А.А. Защита сахарной свеклы от сорняков // Защита и карантин растений. 2005. № 10. C. $17-18$.

11. Иващенко А.А. Современные тенденции защиты сахарной свеклы от сорняков // Защита и карантин растений. 2005. № 2. С. 26-30.

12. Государственный каталог пестицидов и агрохимикатов, разрешенных к применению на территории Российской Федерации. Часть І. Пестициды. М.: Министерство сельского хозяйства, 2020. 830 с.

13. European Food Safety Authority, Anastassiadou M., Brancato A., Carrasco Cabrera L., Ferreira L., Greco L., Jarrah S., Kazocina A., Leuschner R., Magrans J.O., Miron I., Pedersen R., Raczyk M., Reich H., Ruocco S., Sacchi A., Santos M., Stanek A., Tarazona J., Theobald A., Verani A. Review of the existing maximum residue levels for clethodim according to Article 12 of Regulation (EC) No 396/2005. EFSA Journal. 2019. Vol. 17. № 5. P. 5706. doi: 10.2903/j.efsa.2019.5706

14. Osterholt M., Webster E., Blouin D., McKnight B. Overlay of residual herbicides in rice for improved weed management. Weed Technology. 2019. Vol. 33. № 3. Pp. 426-430. doi: 10.1017/wet.2019.223 p.

15. Mesnage R., Biserni M., Balu S., Frainay C., Poupin N., Jourdan F. et al. Integrated transcriptomics and metabolomics reveal signatures of lipid metabolism dysregulation in HepaRG liver cells exposed to PCB126. Arch. Toxicol. 2018. Vol. 92(8). Pp. 2533-2547. doi: 10.1007/s00204-018-2235-7

16. Mesnage R., Biserni M., Wozniak E., Xenakis T., Mein C.A., Antoniou M.N. Comparison of transcriptome responses to glyphosate, isoxaflutole, quizalofop-p-ethyl and mesotrione in the HepaRG cell line. Toxicol. 2018. № 5. Pp. 819—826. doi: 10.1016/j.toxrep.2018.08.005

17. Biserni M., Mesnage R., Ferro R., Wozniak E., Xenakis T., Mein C.A., et al. Quizalofop-p-Ethyl Induces Adipogenesis in 3T3-L1 Adipocytes. Toxicological Sciences. 2019. Vol. 170. № 2. Pp. 452 —461. doi: 10.1093/toxsci/ kfz097

18. Jankowska M., Kaczynski P., Lozowicka B. Metabolic profile and behavior of clethodim and spirotetramat in herbs during plant growth and processing under controlled conditions. Scientific Reports. 2020. Vol. 10 . № 1. Pp. 1323. doi: 10.1038/s41598-020-58130-3

19. Guldiken B., Ozkan G., Catalkaya G., Ceylan F.D., Yalcinkaya I.E., Capanoglu E. Phytochemicals of herbs and spices: Health versus toxicological effects. Food and Chemical Toxicology. 2018. № 119. Pp. 37—49. doi: 10.1016/j.fct.2018.05.050

\section{Об авторах:}

Крюкова Кристина Дмитриевна - магистрант, Агробиотехнологический департамент, Аграрно-технологический институт, Российский университет дружбы народов, 117198, Российская Федерация, г. Москва, ул. Миклухо-Маклая, д. 8/2; e-mail: k_kryukova@inbox.ru

Гресис Валерия Олеговна - аспирант, Агробиотехнологический департамент, Аграрно-технологический институт, Российский университет дружбы народов, 117198, Российская Федерация, г. Москва, ул. Миклухо-Маклая, д. 8/2; e-mail: gresis_vo@pfur.ru 